concerned. Courses ranging from a week-end to a month were devoted to instructor training, to the general educational needs of people shortly to be demobilized, and to social and leisure interests. The value of these residential colleges in a university atmosphere has been recognized by both Forces education officers and civilians alike, and there seems little doubt that these colleges are making a distinctive contribution to Service education out of all proportion to the small numbers who can attend.

The needs of the Forces overseas have increased, and many regional committees were generous in releasing both full-time lecturers and members of their part-time panels to spend one month or more with Commands overseas ; visits have already been made to Germany, Italy, Austria, the Middle East, India, Ceylon and Burma. Two of the lecturers, Dr. Gavin Henderson and Dr. J. W. Jenkins, lost their lives during their periods of work overseas.

\section{ANGLO-AMERICAN CARIBBEAN COMMISSION}

$\mathrm{T}$ HE report of the Anglo-American Caribbean Commission to the Governments of the United States and Great Britain for the year 1944*, publication of which has been delayed by war-time shortage of staff, refers to the Land Tenure Symposium at Puerto Rico, August 27-September 2, 1944, held in accordance with a recommendation of the Caribbean Research Council, which included technical papers from specialists, informal discussions and tours of the research and educational institutions and of the landtenure improvement projects in Puerto Rico. Questionnaires prepared and sent out by the Research Council during the year relating to crop growing and animal husbandry within the Caribbean covered sugar, livestock, grain crops, grasses and grassland management, root crops and pulses, and vegetables. The Committee on Agriculture has requested from each department of agriculture and research institution in the area a complete list of addresses to which its publications have been sent and a list of research workers within its field of specialization, from which lists it is proposed to compile for circulation a comprehensive mailing list and a list of research workers and their subjects. Dr. C. E. Charden, director of the Institute of Tropical Agriculture, Mayaguez, Puerto Rico, visited Barbados and Trinidad in December 1944 in connexion with the joint survey of agricultural research agencies to be made by him and Prof. D. D. Paterson of the Imperial College of Tropical Agriculture, Trinidad. Dr. Paterson visited Puerto Rico in the spring of 1945 and a joint report is being compiled.

Further work of the Anglo-American fishery survey during 1944 explored the resources within the Eastern Group of the British West Indies and was extended up to nine months in the waters of Trinidad, Tobago and British Guiana. The results of the otter trawling and the interest displayed by local fishermen led to the publication of a pamphlet describing the construction and use of small otter trawls suitable for local use. A report on the survey will shortly be published as a special bulletin, and a practical and

*Anglo-American Caribbean Commission, 810 18th Street N.W., Washington, D.C. comprehensive guide on shark fishing has been prepared and issued for the use of the fishermen themselves.

A joint programme for the control of venereal disease has been initiated with permanent head. quarters in Port-of-Spain, and this Caribbean Medical Centre, in addition to conducting serological surveys, treating patients, and educating the public to the necessity of diagnosis and treatment, is conducting an intensive training programme of local personnel. Dr. R. Kahn visited the Centre, at the invitation of the Trinidad Government, to investigate and advise on the serological reactions for syphilis, especially in regard to the standardization of serological technique in the Caribbean and to bring up-to-date knowledge of the role of serology in syphilis control. The exchange of visits of outstanding men of science between the United States, Canada and Great Britain and the Caribbean area to exchange knowledge and stimulate research is a major objective of the Commission.

A West Indian Medical Conference at Trinidad was attended by representatives of all the medical departments of the British Colonies, while the necessary steps to set up the Caribbean Research Council and the four recommended research committees, dealing with public health and medicine, industries, building and engineering research and social science have now been taken at the sixth meeting of the Commission in Washington in March 1945, following on meetings of the Provisional Committees at St. Thomas in September 1944, when recommendations for membership and for the field of work of the Permanent Committees were made to the Council. The report also stresses the value of the West Indian Conference at Barbados in March 1944, and the Commission itself examined the question of the practicability of another such conference. While the conclusion was reluctantly reached that this was impracticable, it is hoped that a second West Indian Conference will be announced in due course ; the Provisional Committee of the Caribbean Research Council has already recommended the establishment of a central secretariat to serve all committees and to work in liaison with the executive secretaries of the Commission. The Commission has also considered the creation of a permanent conference secretariat, but without regarding the matter as urgent pending the fixing of the date of the second conference.

\section{ROYAL COLLEGE OF SURGEONS SCIENTIFIC REPORT FOR 1944-45}

$T$ HE Scientific Report of the Royal College of Surgeons for the year 1944-45 records welcome progress in reconstruction and reassembly of specimens dispersed during the War. Prof. R. A. Willis, the newly appointed Sir William H. Collins professor of human and comparative pathology, reports the return to the College of specimens which have been acquired since the disaster which the Museum suffered in 1941. There are more than six hundred of them, and they have been so well cared for during their dispersal that most of them have been added to the Museum. Prof. Willis and his staff have spent much time on problems of reconstruction, building, illumination and display of specimens. This report gives a list of the additions made to the Museum. 